\title{
Leber congenital amaurosis RPE65: 7 years follow up
}

\author{
Jorge Arturo Sánchez-Ramos, Ángeles Yahel Hernández-Vázquez and Juan Abel Ramírez-Estudillo \\ Department of Retina and Corpus Vítreum, Fundación Hospital Nuestra Señora de la Luz, Ciudad de México, Mexico
}

\begin{abstract}
Leber congenital amaurosis is a retinal dystrophy with several forms of presentation due to its genetic variability. Case of a female girl followed up from 4 to 11 years old is presented, with positive clinical data of nyctalopia, myopia and choroid ocular fundus. Electroretinogram was not measurable in all phases but diagnostic was confirmed by RPE65 mutation genetic study RPE65 Leber congenital amaurosis is particularly important as it has been researched for a gene therapy treatment with good functional outcomes up to now, awaiting to offer hope and a better quality of life to people with this disease.
\end{abstract}

KEY WORDS: Leber congenital amaurosis. Nyctalopia. Gene therapy.

\section{Introduction}

Leber congenital amaurosis was described in 1869 and it involves a genetically heterogeneous group of retinal dystrophies characterized by low visual acuity at early ages ${ }^{1}$, as well as nystagmus, pigmentation changes in the fundus and, characteristically, an abolished eletroretinogram ${ }^{2,3}$. The clinical variability spectrum is very broad, and it is specifically associated with the gene that is affected ${ }^{4-8}$. Specifically, in the RPE65 (retinal pigment-specific 65-kDa) mutation, photon-absorption capability of photoreceptor visual pigments to continue the visual cycle is affected ${ }^{9}$.

\section{Case presentation}

This is the case of an 11-year-old patient, native to Mexico City, who had a genetic makeup for high blood pressure and ischemic heart disease. She had no relevant ophthalmologic family history. Her mother referred she used eyeglasses for vision correction since 4 years of age. Her current complaint had started since she was 3 , as her parents constantly noticed poor vision at night. On physical examination at 4 years of age, her counting fingers visual acuity was with $-6.00-3.50 \times 180$ refraction in the right eye and $-6.00-3.00 \times 0$ in the left eye. Both eyes' biomicroscopy didn't reveal relevant data and pupillary reflexes were normal.

On fundus examination, choroidal fundus was observed with presence of small punctate lesions of yellowish white color at the equatorial level (Fig. 1).

Complementary tests included an electroretinogram, which was not measurable at both photopic and scotopic phases on both eyes (Fig. 2).

Eyeglasses were offered for vision correction and the patient remained under surveillance with periodic examinations. As years went by, visual acuity examination became more reliable, with right eye visual acuity of 20/400 in 2015, which was improved to $20 / 50$ with a $-4.75-3.00 \times 5$ refraction, and left eye visual acuity of $20 / 533$, which was improved to 20/50 with -5.00 -3.00 x 175 refraction. During her follow-up, new fundus photographs were obtained, as well as a computerized kinetic visual field (Figs. 3 and 4).

\author{
Correspondence: \\ Jorge Arturo Sánchez-Ramos \\ Ezequiel Montes, 135 \\ Col. Tabacalera, Del. Cuauhtémoc \\ C.P. 06030, Ciudad de México, México \\ E-mail: jorgesr84@ hotmail.com
}

Date of reception: 18-10-2016

Date of acceptance: 06-12-2016

DOI://dx.doi.org/10.24875/GMM.M18000099
Gac Med Mex. 2017;153:837-840

Contents available at PubMed www.gacetamedicademexico.com 

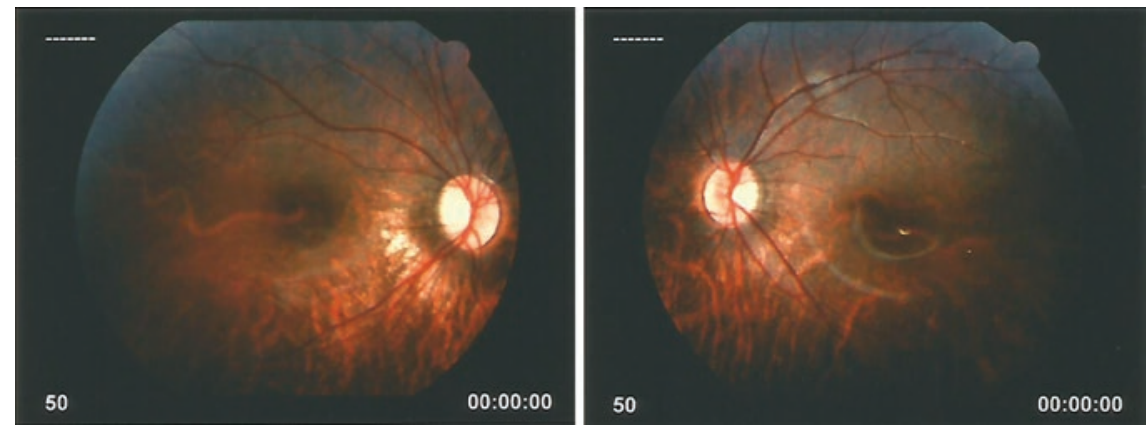

Figure 1. Fundus examination photograph at 4 years of age, where the fundus choroid and some pigmentation changes at the equatorial level are observed.

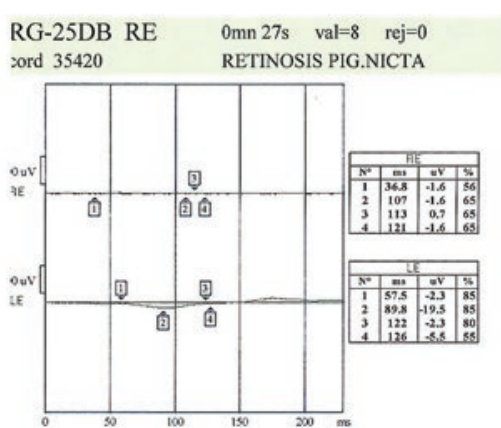

$\begin{array}{ll}\text { RG-POSC RE } & 3 \mathrm{mn} 33 \mathrm{~s} \quad \text { val }=8 \quad \text { rej }=0 \\ \text { sord } 35423 & \text { RETINOSIS PIG.NICTA }\end{array}$

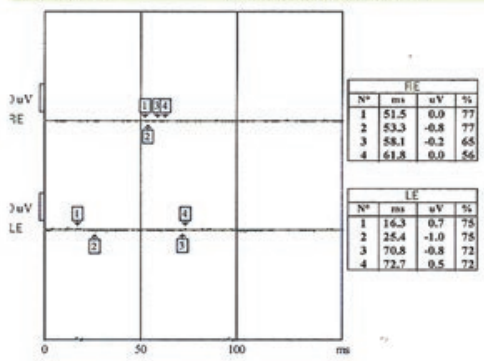

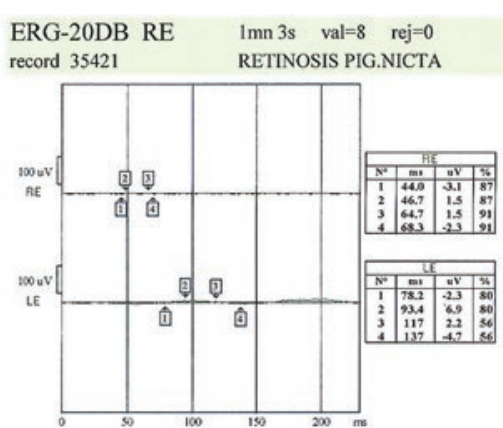

$\begin{array}{ll}\text { ERG-CONE LE } & 9 \mathrm{mn} 51 \mathrm{~s} \quad \text { val }=30 \quad \text { rej }=0 \\ \text { record } 35430 & \text { RETINOSIS PIG.NICTA }\end{array}$

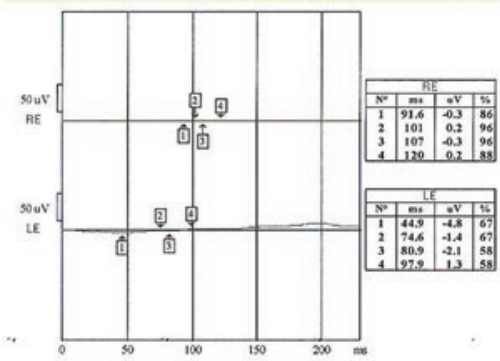

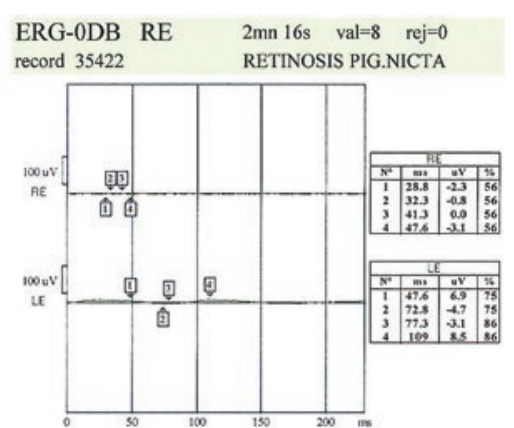

ERGWFL30 LE $\quad 10 \mathrm{mn} 17 \mathrm{~s} \quad$ val $=30 \quad$ rej $=0$ $\begin{array}{ll}\text { record } 35431 & \text { RETINOSIS PIG.NICTA }\end{array}$

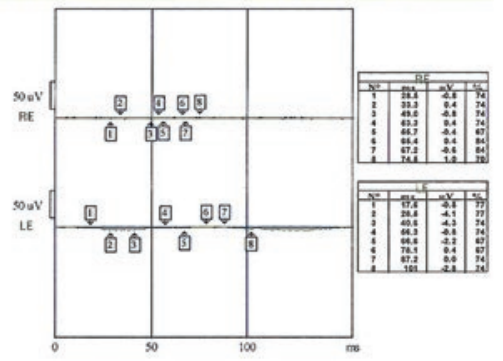

Figure 2. Electroretinogram at 4 years of age, with non-measurable responses on both eyes and at all its phases.

In view of diagnostic suspicion, a SANGER-type genetic sequencing test was performed, where an adenine insertion at position 1067, which generated a reading frame shift in the paternal allele, and a cytosine change for thymine at position 700 , thus determining a compound heterozygous mutation with an autosomal recessive inheritance pattern in the maternal allele, which allowed for the RPE65 Leber congenital amaurosis to be corroborated. The patient remains under surveillance only with eyeglasses for vision correction and carries out her school activities without any limitation.

\section{Discussion}

As we could observe, the main symptom of this patient was nyctalopia, identified by their parents, and not the classical data described in the literature, such as poor visual acuity at early ages, Franceschetti's oculo-digital sign, presence of nystagmus or altered pupillary reflexes. This is because there is great genetic variability associated with different phenotypes in this pathology ${ }^{10,11}$. In the case of the RPE65 mutation, characteristic clinical data have been described, such as the presence of nyctalopia, good visual acuity during childhood (which usually worsens at the second decade of life), association with short-sightedness, chorioretinal atrophy and presence choroidal fundus, as observed in our patient ${ }^{12}$.

There are several differential diagnoses that should be taking into account with a patient presenting with nyctalopia. Table 1 shows some of the main diagnoses to be considered, with their most relevant clinical features. 

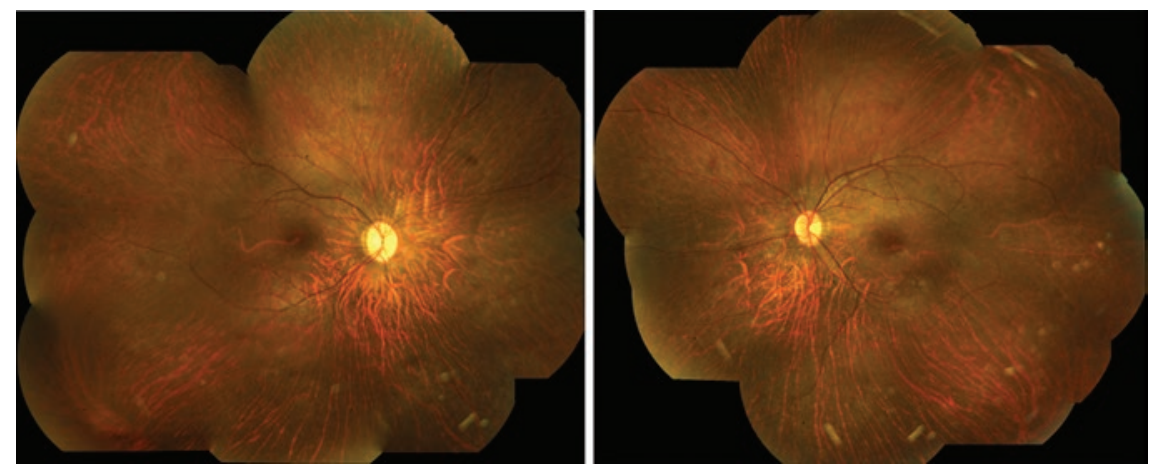

Figure 3. Fundus photographic composition at 11 years of age, where choroidal fundus and pigmentary changes at the equatorial and peripheral levels are observed.

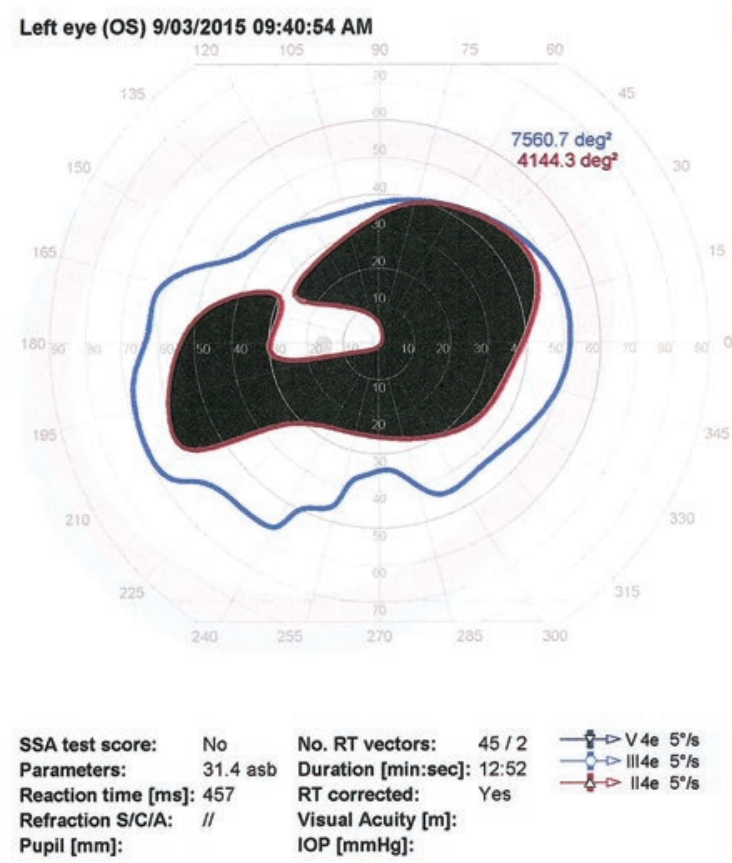

Right eye (OD) 9/03/2015 09:17:59 AM

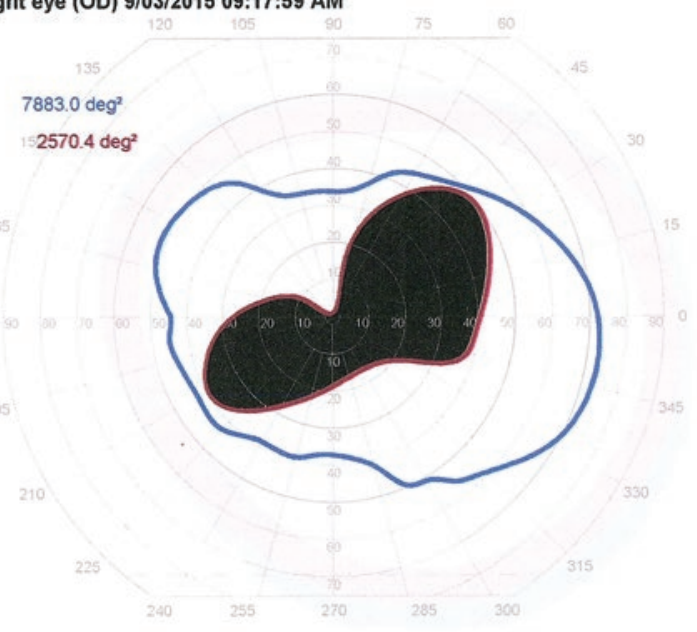

SSA test score: No

No. RT vectors: $45 / 2 \rightarrow \forall-\rightarrow$ Ve $5 \%$ 31.4 asb Duration [min:sec]: 14:16 $\Leftrightarrow \rightarrow \| 4$ e $5 \%$ Reaction time [ms]: $642 \quad$ RT corrected: Yes $\rightarrow \| 4 e^{\circ} \%$ Refraction S/C/A: "I Visual Acuity [m]: Pupil [mm]: IOP [mmH]:

Figure 4. Computerized kinetic visual field, where generalized concentric reduction is observed in both eyes. The right eye has a central scotoma that extends to the superior temporal sector and inferior nasal the left eye has a paracentral scotoma that extends to the superior nasal sector and in the $20^{\circ}$ inferior up to $60^{\circ}$ temporal.

The RPE 65 mutation has special characteristics within Leber congenital amaurosis varieties, since genetic involvement is well known and, although poor visual acuity is early, photoreceptor morphogenesis is normal, and they remain healthy until late stages of the disease ${ }^{9}$. The latter characteristic has enabled the development of treatment modalities such as gene therapy, which consists of subretinal injection of adenoviruses modified with RPE65 DNA with the purpose to improve photoreceptor function and allow for the visual cycle to be completed. This treatment has shown its effectiveness in animal models, and the goals of the treatment are focused not only on preventing visual acuity loss, but on improving $\mathrm{it}^{13,14-16}$.
In some works, the vector was tried to be applied in an intravitreal manner, but the presence proteoglycans in the internal limiting membrane is thought to have limited its passage to retinal deep layers, where photoreceptors are found, thus decreasing its effectiveness. In addition, the vector was tried to be injected into the suprachoroidal space, but it had a very rapid clearance owing to the high vascular flow found in the choroid ${ }^{13,14-16}$.

Studies that have assessed the response to this treatment report visual acuity improvement, increased sensitivity in the perimeter and visual fields, and higher response in pupillary reflexes ${ }^{13-17}$. 
Table 1. Main nyctalopia differential diagnoses

\begin{tabular}{|c|c|c|c|c|c|c|c|c|}
\hline & \multicolumn{6}{|c|}{ Congenital stationary night blindness } & \multirow{2}{*}{$\begin{array}{l}\text { Retinitis } \\
\text { pigmentosa }\end{array}$} & \multirow{2}{*}{$\begin{array}{l}\text { Leber } \\
\text { congenital } \\
\text { amaurosis }\end{array}$} \\
\hline & $\begin{array}{l}\text { Riggs } \\
\text { type } 1\end{array}$ & $\begin{array}{l}\text { Shubert } \\
\text { complete } \\
\text { type } 1\end{array}$ & $\begin{array}{l}\text { Shubert } \\
\text { incomplete } \\
\text { type } 1\end{array}$ & Oguchi disease & $\begin{array}{l}\text { Fundus } \\
\text { albipuntatus }\end{array}$ & $\begin{array}{l}\text { Kandori } \\
\text { flecks }\end{array}$ & & \\
\hline Nyctalopia & Yes & Yes & Yes & Yes & Yes & Yes & Yes & Yes \\
\hline Fundus & Normal & Normal & Normal & $\begin{array}{l}\text { Mizuo-Nakamura } \\
\text { phenomenon }\end{array}$ & $\begin{array}{l}\text { Yellowish } \\
\text { white dots }\end{array}$ & $\begin{array}{l}\text { Irregular } \\
\text { flecks }\end{array}$ & $\begin{array}{l}\text { Bone spicules, } \\
\text { pale papilla, } \\
\text { vascular } \\
\text { attenuation, } \\
\text { vitreous pigment }\end{array}$ & Very variable \\
\hline Visual field & Normal & Normal & Normal & Normal & Normal & Normal & $\begin{array}{l}\text { Concentric } \\
\text { decrease }\end{array}$ & $\begin{array}{l}\text { Sensitivity } \\
\text { decrease with } \\
\text { no characteristic } \\
\text { pattern }\end{array}$ \\
\hline Electroretinogram & $\begin{array}{l}\text { Scotopic } \\
\text { phase } \\
\text { A and B } \\
\text { waves } \\
\text { decrease }\end{array}$ & $\begin{array}{l}\text { Scotopic } \\
\text { phase } \\
\text { B wave } \\
\text { decrease }\end{array}$ & $\begin{array}{l}\text { Scotopic } \\
\text { and } \\
\text { photopic } \\
\text { phases } \\
\text { B wave } \\
\text { decrease }\end{array}$ & $\begin{array}{l}\text { B wave decrease } \\
\text { that improves after a } \\
\text { period of adaptation } \\
\text { to darkness ( } 30 \mathrm{~min})\end{array}$ & $\begin{array}{l}\text { B wave } \\
\text { decrease that } \\
\text { improves after } \\
1-3 \text { hours of } \\
\text { adaptation to } \\
\text { darkness }\end{array}$ & $\begin{array}{l}\text { Normal with } \\
\text { adaptation } \\
\text { to } \\
\text { prolonged } \\
\text { darkness }\end{array}$ & $\begin{array}{l}\text { Initial phase: } \\
\text { scotopic response } \\
\text { decrease } \\
\text { Late phase: } \\
\text { scotopic and } \\
\text { photopic response } \\
\text { decrease }\end{array}$ & $\begin{array}{l}\text { Non-measurable } \\
\text { since early ages }\end{array}$ \\
\hline
\end{tabular}

In spite of the efforts made in these investigations, long-term results appear to be still insufficient to be able to standardize the treatment method and achieve a significant and lasting visual improvement ${ }^{18}$; however, it is necessary for patients with the RPE 65 to be identified, so that in the near future, when such a treatment is available, being able to offer it to them and hence prevent their visual deterioration.

\section{Conclusion}

Leber congenital amaurosis ir a rare condition associated with poor visual acuity at early ages. There is great variability of presentation related to the genotype. The RPE65 variant has a favorable evolution at least during the first years, and its characteristics make it attractive for the study of genetic treatments that in the future might modify the natural evolution of this disease.

\section{Acknowledgements}

To Instituto de Oftalmología Conde de Valenciana genetics laboratory for its participation in the diagnostic corroboration of this case.

\section{References}

1. Leber T. Ueber Retinitis Pigmentosa und Augeborene Amaurose. Albrecht von Graefes Arch Ophthalmol. 1869;15:1-25.
2. Nickel B, Hoyt CS. Leber's congenital amaurosis: is mental retardation a frequent associated defect? Arch Ophthalmol. 1982;100:1089-92.

3. Schroeder R, Mets MB, Maumenee IH. Leber's congenital amaurosis: retrospective review of 43 cases and a new fundus finding in two cases. Arch Ophthalmol. 1987;105:356-9.

4. Koenekoop RK, Loyer M, Dembinska O, et al. Visual improvement in Leber congenital amaurosis and the CRX genotype. Ophthalmic Genet. 2002;23:49-59.

5. Dharmaraj S, Silva E, Pina A, et al. Mutational analysis and clinical correlation in Leber congenital amaurosis. Ophthalmic Genet. 2000; 21:135-50.

6. Sohocki M, Perrault I, Leroy B, et al. Prevalence of AIPL1 mutations in inherited retinal degenerative disease. Mol Genet Metab. 2000;70:142-50.

7. Sohocki M, Bowne S, Sullivan L, et al. Mutations in a new photoreceptor-pineal gene on 17p cause Leber congenital amaurosis. Nat Genet. 2000;24:79-83.

8. Lotery A, Jacobson S, Fishman G, et al. Mutations in the CRB1 gene cause Leber congenital amaurosis. Arch Ophthalmol. 2001;119:415-20.

9. Hauswirth W, Aleman T, Kaushal S. Treatment of Leber congenital amaurosis due to RPE65 mutations by ocular subretinal injection of adeno-associated virus gene vector: short-term results of a phase I trial. Hum Gene Ther. 2008;19:979-90.

10. Lambert SR, Kriss A, Taylor D, et al. Follow-up and diagnostic reappraisal of 75 patients with Leber's congenital amaurosis. Am J Ophthalmol. 1989;107:624-31.

11. Koenekoop RK. An overview of Leber congenital amaurosis: a model to understand human retinal development. Surv Ophthalmol. 2004; 49:379-98.

12. Galvin J, Fishman G, Stone E. Evaluation of genotype-phenotype associations in Leber congenital amaurosis. Retina. 2005;25:919-29.

13. Bainbridge J, Smith A, Barker S, et al. Effect of gene therapy on visual function in Leber's congenital amaurosis. N Engl J Med. 2008; 358:2231-9.

14. Maguire AM, Simonelli F, Pierce EA, et al. Safety and efficacy of gene transfer for Leber's congenital amaurosis. N Engl J Med. 2008;358:2240-8.

15. Jacobson SG, Cideciyan AV, Ratnakaram R, et al. Gene therapy for Leber congenital amaurosis caused by RPE65 mutations: safety and efficacy in 15 children and adults followed up to 3 years. Arch Ophthalmol. 2012;130:9-24.

16. Testa F, Maguire AM, Rossi S, et al. Three-year follow-up after unilateral subretinal delivery of adeno-associated virus in patients with Leber congenital amaurosis type 2. Ophthalmology. 2013;120:1283-91.

17. Maguire AM, High KA, Auricchio A, et al. Age-dependent effects of RPE65 gene therapy for Leber's congenital amaurosis: a phase 1 dose-escalation trial. Lancet. 2009:374:1597-605.

18. Bainbridge JWB, Mehat MS, Sundaram V, et al. Long-term effect of gene therapy on Leber's congenital amaurosis. N Engl J Med. 2015;372:1887-97. 